\title{
Rhinoclemmys areolata (Duméril and Bibron 1851) - Furrowed Wood Turtle, Black-Bellied Turtle, Mojena
}

\author{
Richard C. Vogt ${ }^{1}$, Steven G. Platt ${ }^{2}$, and Thomas R. Rainwater ${ }^{3}$ \\ ${ }^{1}$ CPBA/INPA, Caixa Postal 478, Petropolis, Manaus, AM 69011-970, Brazil [vogt@inpa.gov.br]; \\ ${ }^{2}$ Department of Biology, P.O. Box C-64, Sul Ross State University, \\ Alpine, Texas 79832 USA [sgplatt@gmail.com]; \\ ${ }^{3}$ The Institute of Environmental and Human Health, Department of Environmental Toxicology, \\ Texas Tech University, P.O.Box 764,Jefferson, Texas, 75657 USA [thomas.rainwater@tiehh.ttu.edu]
}

Summary. - Rhinoclemmys areolata (Family Geoemydidae) is a medium-sized, semi-terrestrial turtle common to southeastern Mexico and the Yucatan Peninsula, the Petén region of Guatemala, Belize, and northwestern Honduras. Rhinoclemmys areolata feeds primarily on herbaceous plants, but also consumes fruits, insects, and occasionally carrion. This species is characterized by a small clutch of 1 to 2 large eggs. Populations do not seem to be threatened at this time.

Distribution. - Belize, Guatemala, Honduras, Mexico. Distributed from southern Veracruz southwards through the Yucatan Peninsula in Mexico, northern Guatemala, throughout Belize, and northwestern Honduras.

Synonymy. - Emys areolata Duméril and Bibron 1851, Malaclemmys concentrica areolata, Malaclemys concentrica areolata, Clemmys areolata, Chelopus areolatus, Nicoria punctularia areolata, Geoemyda punctularia areolata, Geoemyda areolata, Geomyda punctularia areolata, Geomyda areolata, Rhinoclemys areolata, Rhinoclemmys areolata, Callopsis areolata.

SuBSPECIES. - None recognized.

StaTuS. - IUCN 2008 Red List: Near Threatened (LR/nt) (assessed 2007); CITES: Not Listed.

Taxonomy. - Rhinoclemmys areolata has been associated with nine different generic names (Emys, Malaclemmys, Clemmys, Nicoria, Geomyda, Geoemyda, Rhinoclemmys, Rhinoclemys, and Callopsis; however, the taxonomy of this species is straight-forward and no nomenclaturally occupied synonyms have been acquired.
Complete synomomies are listed in Smith and Smith (1979), Ernst (1980), and Fritz and Havas (2007). Although both Ernst (1978) and Perez-Higareda and Smith (1987) noted variation in head color patterns among different populations, these characteristics were not consistent enough to warrant subspecific designations.

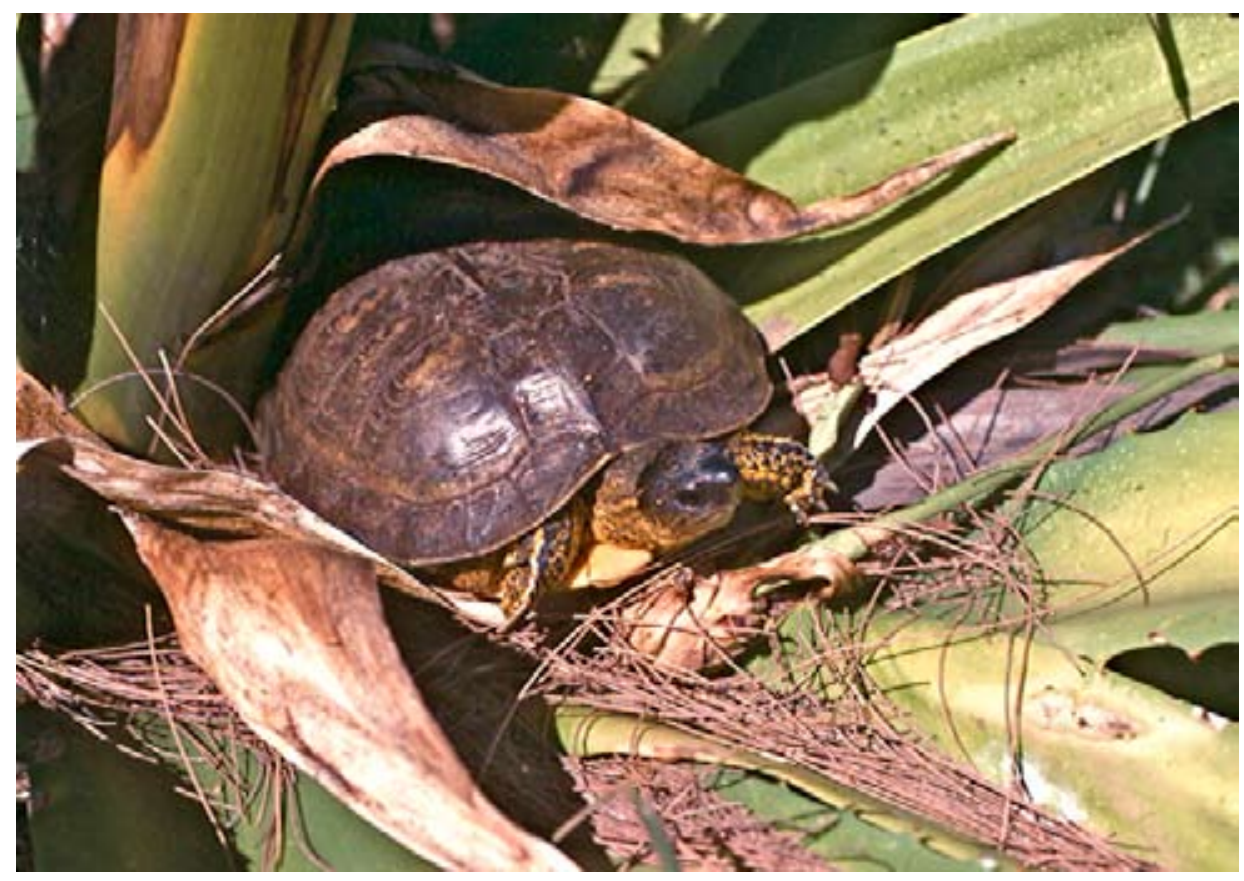

Figure 1. Rhinoclemmys areolata from Lerdo de Tejada, Veracruz, Mexico. Photo by Richard C. Vogt. 


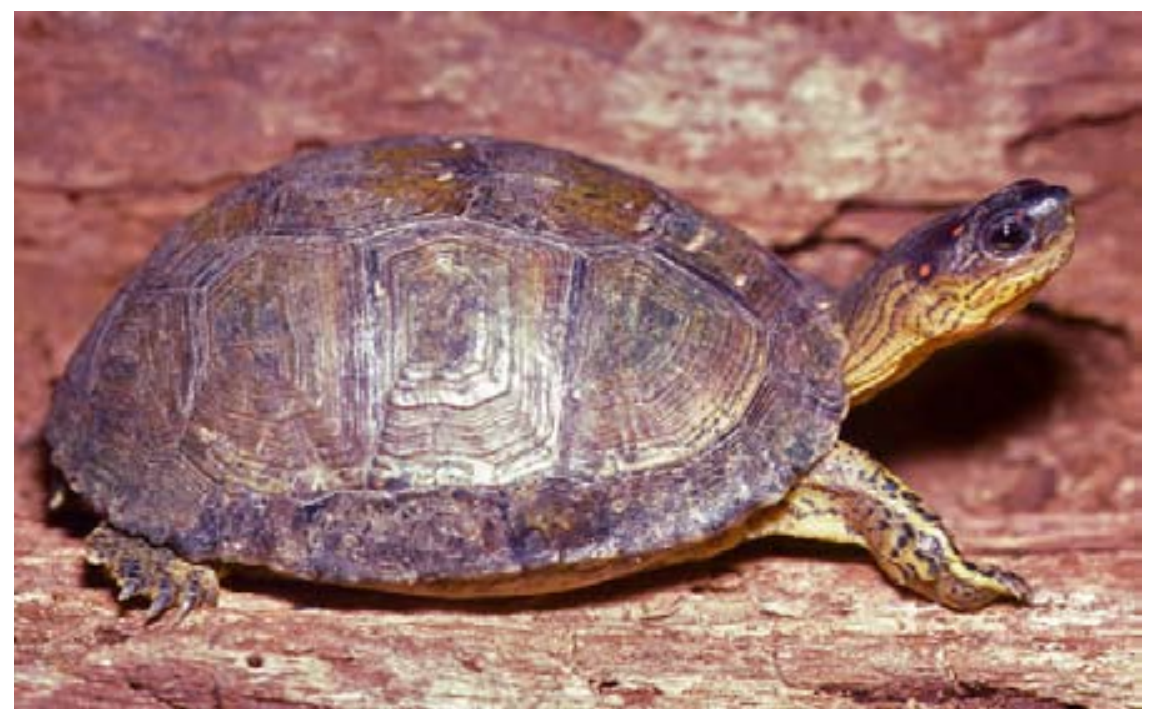

Figure 2. Rhinoclemmys areolata from near Paamul, Quintana Roo, Mexico. Photo by John B. Iverson.

Description. - Rhinoclemmys areolata is a mediumsized turtle with a high, domed shell reaching $207 \mathrm{~mm}$ in carapace length (CL) (Platt et al. 2004a). Marginals 8 to 12 are often flared or upturned. The carapace becomes smooth in old adults, but is rugose with distinct annuli in juveniles and subadults. The carapace is brown with dark sutures and yellow mottling. The costal scutes have a red or yellow dark-bordered central spot, which fades with age in some populations and appears to be lacking altogether in Belize populations. The unhinged plastron is complete, dark brown centrally, and bordered by yellow.

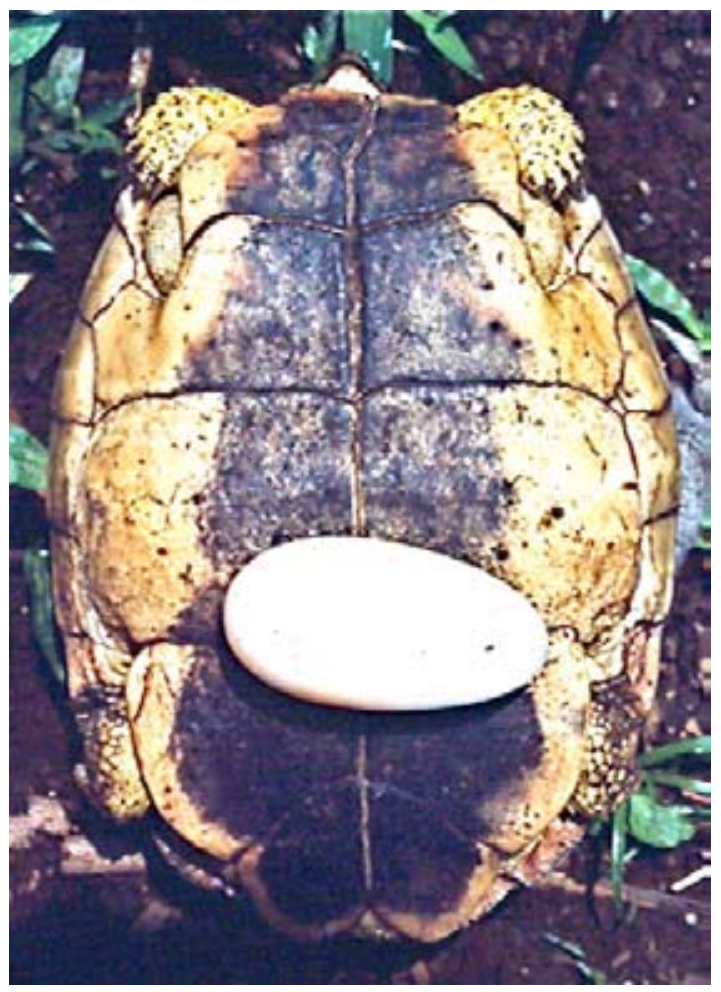

Figure 3. Rhinoclemmys areolata from Lerdo de Tejada, Veracruz, Mexico. Photo by Richard C. Vogt.
The head of $R$. areolata is narrow, with a slightly pointed snout and notched maxilla. The head and neck are brown or light green with a highly variable pattern of red and yellow stripes. Generally, a thin yellow or red stripe runs postocularly to the neck, another stripe is present between the eye and the tympanum, and two yellow or red stripes are usually present on the nape of the neck. Often a yellow stripe is present along the upper jaw from the snout to the tympanum. The mandible is lighter, usually yellow with black spots. The feet are barely webbed. The forelimbs are generally yellow with black spots. In males, the tail is elongated and thicker at the base and the plastron is slightly concave. Females in Belize are considerably larger than males; in a sample of over 200 turtles, the five largest individuals were females that measured 173-180 mm CL, and had a mass of 630-930 g (Platt and Rainwater, unpubl. data). Sex can be determined at a CL of ca. $110 \mathrm{~mm}$. Adult turtles have at least 9-10 plastral annuli.

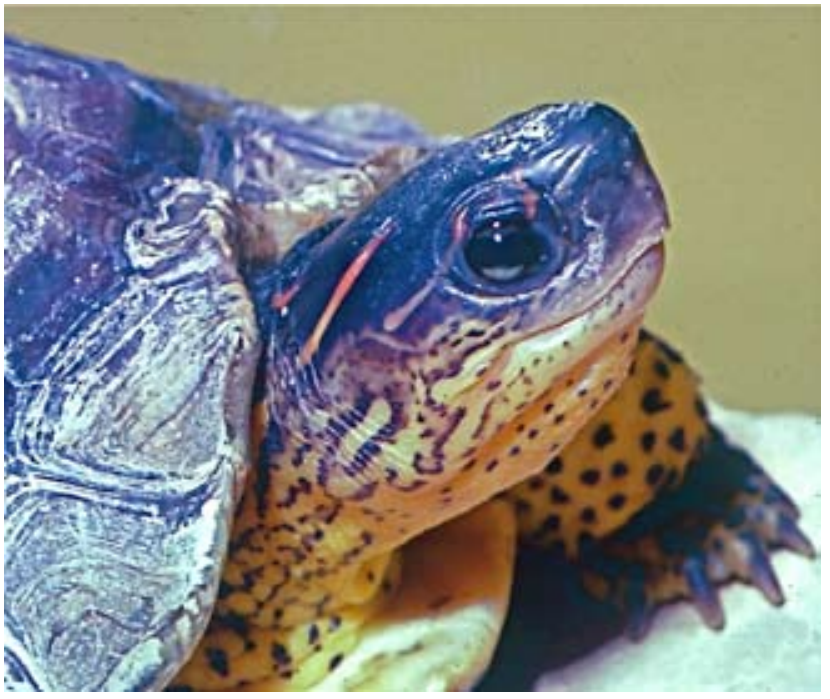

Figure 4. Rhinoclemmys areolata, captive animal of unknown origin. Photo by James H. Harding. 


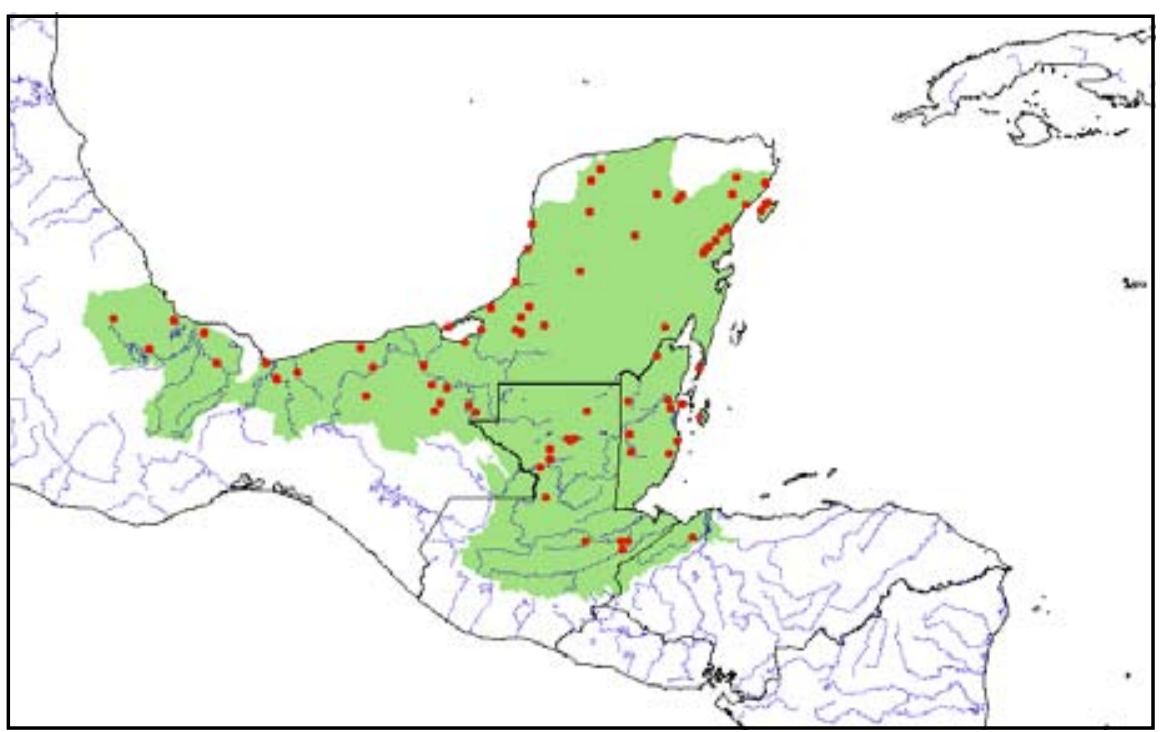

Figure 5. Distribution of Rhinoclemmys areolata in southern Mexico and northern Central America. Red points = museum and literature occurrence records based on Iverson (1992) plus more recent and authors' data; green shading = projected distribution based on GISdefined hydrologic unit compartments (HUCs) constructed around verified localities and then adding HUCs that connect known point localities in the same watershed or physiographic region, and similar habitats and elevations as verified HUCs (Buhlmann et al., unpubl. data), and adjusted based on authors'data.

Distribution. - Rhinoclemmys areolata occurs from southern Veracruz southwards through the Yucatan Peninsula (including Isla de Cozumel) in Mexico, northern Guatemala, throughout Belize, and northwestern Honduras (Ernst 1980; Iverson 1992; Lee 1996). A population of $R$. areolata also occurs in the Turneffe Atoll, an isolated group of xeric islands in Belize, ca. $35 \mathrm{~km}$ from the mainland (Platt et al. 1999a).

Habitat and Ecology. - Rhinoclemmys areolata inhabits savanna, thorn scrub woodland, broadleaf forest, fallow agricultural land, and marshes throughout its range. In Belize, $R$. areolata is especially abundant in lowland pine communities that are characterized by a mosaic of pine forest and savanna vegetation. This habitat is associated with nutrient poor, acidic soils and dominated by Pinus caribaea (Wright et al. 1959; Furley 1989). Natural and anthropogenic fires are common in lowland pine habitats during the dry season (Platt et al. 2004b). Areas near villages are burned annually, while more remote tracts are burned less frequently (Platt and

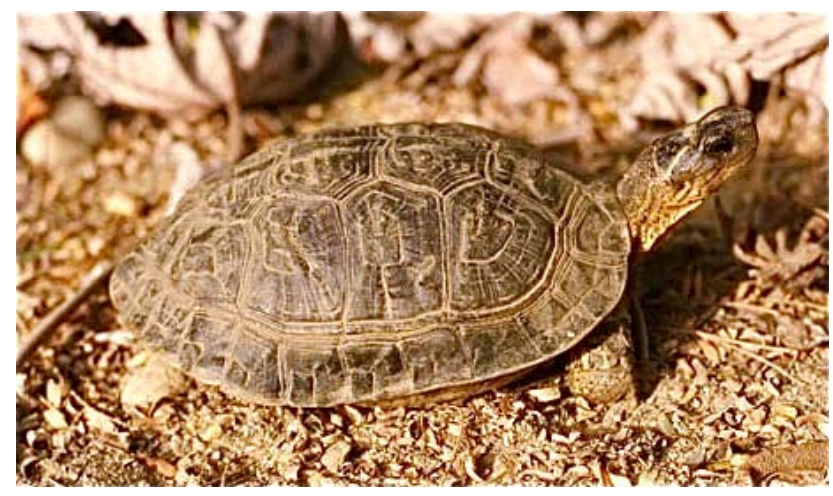

Figure 6. Juvenile Rhinoclemmys areolata from northeastern Oaxaca, Mexico, captive-bred at Centro Mexicano de la Tortuga. Photo by James R. Buskirk.
Rainwater, unpubl. data). It is unclear how $R$. areolata avoid being killed by these fires, but very few $(<10)$ dead turtles were found during an extensive search of recently burned sites in 1997. Turtles may retreat to mesic riparian microhabitats, and nine-banded armadillo (Dasypus
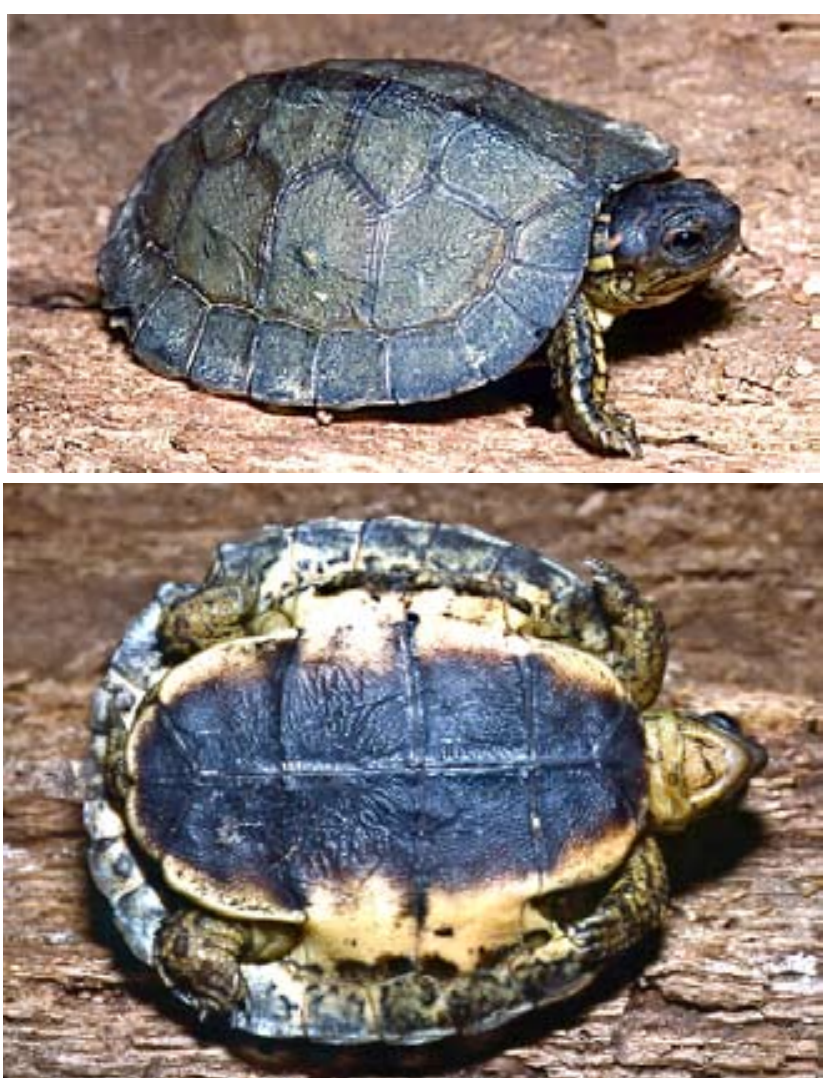

Figure 7.Hatchling Rhinoclemmys areolata from Tulum-Chetumal highway, $59.7 \mathrm{~km}$ SW Coba turnoff, Quintana Roo, Mexico. Photos by John B. Iverson. 
novemcinctus) burrows are probably important refugia from wildlfires (Platt et al. 2004b). Stuart (1935) noted missing feet among many $R$. areolata in the Petén region of Guatemala, and attributed these injuries to wildfires.

Thick growths of carapacial algae and the presence of leeches suggest some individuals spend considerable time in aquatic habitats. In addition, we frequently encountered $R$. areolata foraging in creeks and ephemeral pools, and shells of aquatic snails (Pomacea sp.) were present in some fecal samples. Perez-Higareda and Smith (1988) described a population of $R$. areolata in Tabasco, Mexico that was "essentially aquatic" and noted that courtship and mating occurred underwater.

Although $R$. areolata does not excavate burrows, turtles will occupy those of other animals, particularly nine-banded armadillos. Six adults tracked in Belize with thread-spool trailing devices remained in armadillo burrows for up to 48 hrs, another adult was observed entering a burrow, and turtle tracks were occasionally found at burrow entrances (Platt et al. 2004b).

Little is known regarding predation of adult $R$. areolata . Jaguar (Panthera onca) and puma (Puma concolor) likely consume $R$. areolata on occasion (Emmons 1989; Adams et al. 2006), and Platt and Rainwater (unpubl. data) found the remains of an adult killed and partially eaten by a large felid (both jaguar and puma were present in the area). Juvenile turtles undoubtedly fall victim to a host of reptile, avian, and mammalian predators. When threatened by a predator, adult $R$. areolata assume a defensive posture with the carapace directed towards the predator and the head and legs drawn beneath the shell (Dodd 1978).

The diet of $R$. areolata varies seasonally in Belize (Platt and Rainwater, unpubl. data). During the dry season (January to mid-June) Sauvagesia erecta, a low herb abundant in pinelands, is the primary food. After the wet season begins in mid- to late June, the diet is diversified with the addition of herbaceous legumes and fruits such as Eugenia and Miconia. Craboo (Byrsonima crassifolia) becomes a major component of the diet, both in terms of mass and frequency of occurrence, once fruiting begins in mid- to late July. Some turtles consume large numbers of craboo fruit as evidenced by the scat of an adult female that contained 116 seeds. Preliminary data (Platt and Rainwater, unpubl. data) suggest that craboo seeds require two to four days to pass through the gut. It is probable that $R$. areolata is an important seed disperser for craboo and perhaps other woody shrubs in pine habitats. Craboo cease fruiting in late September, at which time herbaceous vegetation once again becomes the dietary mainstay.

In addition to fruits and herbaceous material, the exoskeletons of coleoptera and other insects, eggshells, crayfish, shed snake skin, mammal hair and bones, and bird feathers have been found in R. areolata scat (Platt 1993; Platt and Rainwater, unpubl. data). One turtle was found consuming gray fox (Urocyon cinereoargenteus) scat containing rodent hair and partially digested Eugenia fruits, suggesting some mammal remains may be secondarily ingested through coprophagy (Platt and Rainwater, unpubl. data). However, the observation of three adult $R$. areolata feeding on a nine-banded armadillo killed by a jaguar (Panthera onca) indicates that at least some vertebrate remains found in scats are due to direct consumption. The scat of many of larger turtles contained numbers of small stones, which possibly aid in digesting the highly fibrous plant material (Sokol 1971) that comprises much of the diet.

Courtship and mating occur from March through May in Tabasco, Mexico (Perez-Higareda and Smith 1988). Olfactory cues are important, and courtship involves cloacal sniffing followed by vigorous head rubbing by the male prior to mating (Perez-Higareda and Smith 1988). Copulation has been observed among wild turtles in Belize during May, July, August, and September; males appear to track and locate females by following scent trails (Platt and Rainwater, unpubl. data). Approximately three weeks are required for eggshell formation (Ewert et al. 1984).

Egg laying occurs during May and June in Quintana Roo; June, July, and October in Veracruz; and May, June, and July in Belize. The clutch usually consists of a single large, hard-shelled, narrowly ellipsoidal egg. However, a wild-caught female in Belize produced a clutch of two eggs (Platt and Rainwater, unpubl. data), and Ewert et al. (1984) noted that two of $35(5.7 \%)$ clutches deposited by captive females consisted of two eggs. Mean ( \pm 1SD) egg length, width, and mass for a sample of 35 eggs were 61.4 $\pm 4.0 \mathrm{~mm}, 30.3 \pm 1.4 \mathrm{~mm}$, and $35.0 \pm 4.2 \mathrm{~g}$, respectively (Ewert et al. 1984). The posterior junction of the carapace and plastron becomes flexible during laying, allowing the large egg to pass. A female found dead on a road was dissected in April 1997. It contained four enlarged ovarian follicles, suggesting that up to four clutches are laid during a single season in Belize (Platt, unpubl. data). This is consistent with the observation of four corpora lutea scars on the ovaries of females autopsied in Quintana Roo (Vogt, unpubl. data); as well as, the observation by PerezHigareda and Smith (1988) of a recently captured female laying four eggs at intervals of five days. According to Ewert et al. (1984), the normal interclutch interval among captive females is two or more months.

Nest construction by $R$. areolata appears minimal. Two wild nests were found in Belize; one egg was found in a sedge clump after being exposed by a brush fire and another nest consisted of a shallow ( $<2 \mathrm{~cm}$ deep) depression scraped in the soil under a shrub. A wild female was observed laying an egg directly on the ground, while a female in captivity deposited an egg on leaf litter beneath a fallen palm frond (Platt and Rainwater, pers. obs.). Similarly, Perez-Higareda and Smith (1988) observed a captive turtle laying an egg in a shallow depression.

Ewert (1979) reported that incubation requires 120 days at $25^{\circ} \mathrm{C}$ and 66 day at $30^{\circ} \mathrm{C}$. In Belize, eggs hatched after 89 to 90 days under natural temperature regimes (Platt and Rainwater, unpubl. data). However, Highfield 
(1996) noted that the embryo may enter a state of diapause shortly after egg-laying and remain inactive for up to six months before tissue formation begins. Like most species of geoemydids, the sex of $R$. areolata is determined by incubation temperature, with males being produced at $25^{\circ} \mathrm{C}$ and females at $30^{\circ} \mathrm{C}$ (Ewert and Nelson 1991). However, Platt and Rainwater (unpubl.data) noted an almost equal sex ratio in a sample of 141 adults from Belize (61 males : 80 females); whether this reflects the true population sex ratio or a sex-specific bias in turtle catchability is unknown. Hatchling size and mass ranges from 44-48 $\mathrm{mm} \mathrm{CL}$ and 18-22 g, respectively.

In addition to leeches, $R$. areolata are parasitized by Amblyomma sabanerae, a common tick of turtles in the lowland tropics of Central America (Pearse 1936; Robbins et al. 2001). Seasonal differences in tick parasitism were found in northern Belize, and female $R$. areolata had significantly greater tick loads than males. The latter is thought to be due to the larger body size of female $R$. areolata (Robbins et al. 2001). Internal parasites remain largely undocumented, although the trematode Telorchis robustus has been found in $R$. areolata from Mexico (Ernst and Ernst 1975).

Population Status. - Vogt (pers. obs.) sporadically encountered $R$. areolata during 17 years of field work with freshwater turtles in Veracruz, Tabasco, Chiapas, Yucatan, and Quintana Roo, Mexico. Turtles were readily found in Tabasco and often encountered crossing roads in Quintana Roo, particularly after thunderstorms. Three juveniles and five hatchlings were found along an $80 \mathrm{~km}$ stretch of highway in the Yucatan during an afternoon thunderstorm in 1985 (J. Iverson, pers. comm.).

The densest population known to the authors occurs on a Mexican island, the name of which remains confidential to protect the turtles from the pet trade and curiosity seekers. At 0930 hrs on 10 July 1982, Vogt (unpubl. data) collected 38 adults in less than an hour following a thundershower. This series consisted of 14 mature and 11 immature females, and 9 mature and 4 immature males. Most were located by crunching sounds made by the turtles while they fed voraciously on plants. This high population density is attributed to the scarcity of predators on the island. High densities of $R$. areolata were again encountered during a return visit in January 1993, but the sighting of two gray fox on the island is cause for concern. The island is designated as a nature reserve and as such $R$. areolata is legally protected; however, enforcement of protective legislation is generally lax in Mexico.

Surveys conducted from 1992 to 2000 have indicated that $R$. areolata is widespread and abundant in northern Belize, particularly so in lowland pine habitats where preliminary estimates suggest densities of 5-6 turtles per ha (Platt and Rainwater, unpubl. data). Survey data for southern Belize are lacking, but suitable habitat extends southward along the coast to the Guatemalan border and, given the sparse human population density, it is likely that $R$. areolata is common in this region. Rhinoclemmys areolata also occurs in the mountain pine forests of central Belize (B. Means, pers. comm.), but surveys have yet to be conducted in this habitat. To our knowledge, survey data from Guatemala and Honduras are currently unavailable.

Threats to Survival. - Some local populations are undoubtedly threatened by road mortality, as well as overcollection for the food, pet, and curio trades. Rhinoclemmys areolata is occasionally consumed by Mexican rurales, and often sold as tourist curios, stuffed and mounted as playing guitars or other musical instruments. Stuart (1935) noted that Maya Indians in Guatemala hunted $R$. areolata for food during an unusually dry winter. Rural dwellers in Belize occasionally take $R$. areolata for food, but given the abundance of preferred game such as paca (Agouti paca), nine-banded armadillo, collared peccary (Tayassu tajacu), and white-tailed deer (Odocoileus virginianus), this harvest is minimal and probably has little effect on local populations. Rastafarian bands occasionally use intact $R$. areolata shells as percussion instruments, although the number of turtles harvested for this purpose is small. Land clearing for agricultural development around Mennonite settlements in the northern districts of Belize has undoubtedly extirpated some populations, but overall, sufficient habitat remains in the country to support viable populations of $R$. areolata. On a cautionary note, the Turneffe Atoll population could be extirpated if additional littoral forest habitat is cleared for tourist resorts (Platt et al. 1999a, b).

Conservation Measures Taken. - Rhinoclemmys areolata probably occurs in most protected areas throughout its distribution. In northern Belize, $R$. areolata is found in Shipstern Nature Reserve, Crooked Tree Wildlife Sanctuary, Rio Bravo Conservation Area, Community Baboon Sanctuary, Lamanai Archaeological Reserve, and Sibun Forest Reserve (Meerman 1993; Platt and Rainwater, unpubl. data). Data for protected areas in southern Belize are currently unavailable. In Mexico, $R$. areolata is known to occur in the Sian Kaán Biosphere Reserve and protected areas of Isla de Cozumel (Vogt, unpubl. data). The IUCN 2007 Red List designated the species as Near Threatened (van Dijk et al. 2007).

Conservation Measures Proposed. - We recommend that the uncontrolled sale in Mexico of curios made from $R$. areolata be prohibited.

Captive Husbandry. - Rhinoclemmys areolata adapts well to captivity and breeds readily. Highfield (1996) recommended a diet composed of up to $90 \%$ plant matter, primarily leafy green vegetables and some fruit, with low fat dog food and other animal proteins making up the remainder. The species is best housed in a well-vegetated enclosure maintained at $28-32^{\circ} \mathrm{C}$ and provided with a low intensity basking source. Courtship and copulation among captives can occasionally be induced by changing the terrarium substrate (Highfield 1996) or spraying them with water (Ewert 1985). 
Rhinoclemmys areolata is currently propogated in captivity at the Nacajuca turtle facility in Tabasco, Mexico, where copulation, nesting, hatching, and rapid growth of neonates occurs under semi-natural conditions (Vogt, pers. obs.). Adult turtles are maintained in a dirt-floored enclosure with access to a cement pond, and feed readily on both native and cultivated fruits (jobo, nanche, banana, tomato); hatchlings and subadults are housed in an aquatic environment and grow rapidly on a diet of fresh fish and banana. The indigenous people of Tabasco, Yucatan, and Quintana Roo, Mexico often keep large numbers (20-40) of $R$. areolata for many months in small corrals near their kitchens, along with ducks, chickens, and pigs. These turtles are fed table scraps and whatever fruit that falls naturally within their reach. Because most households lack refrigeration, these turtles serve as an important alternative protein source when other meat is unavailable. Unlike other species of turtles, $R$. areolata has never been found offered for sale in restaurants in Mexico ( Vogt, pers. obs.). A road-killed adult female boiled and eaten proved tough and unappetizing (Platt, pers. obs.). The specimens that we dissected did not appear to have enough meat to make commercial production for food an economically feasible endeavor.

Current Research. - Platt and Rainwater are engaged in an ongoing population study, initiated in July 1996 at a site in northern Belize where over $250 R$. areolata have been marked. Approximately 80 to $85 \%$ of these turtles were captured with the assistance of a rat terrier, a small domestic dog breed; typically 2-3 $R$. areolata are found per hour of searching. However, during the dry season (December to mid-June) turtles become noticably scarce and difficult to locate. For example, in 1997 only one turtle was found during March and none in January or February, despite intensive searching.

Acknowledgments. - Bill Hasse and Richard and Carol Foster kindly provided Platt and Rainwater with access to their property in northern Belize where most of our studies of $R$. areolata were conducted. Lewis Medlock assisted with fieldwork. The success of our project was due to the turtle-finding abilities of our dog, Trouble. Comments and literature provided by John Iverson improved an early draft of our manuscript. Fieldwork in Belize by Platt and Rainwater was supported by Wildlife Conservation Society.

\section{LITERATURE CITED}

AdAms, R.B.,Pitman, J.C., And Harveson, L.A. 2006. Texas tortoise (Gopherus berlandieri) consumed by a mountain lion (Puma concolor) in southern Texas. Southwestern Naturalist 51:581-582.

DodD, C.K., JR. 1978. A note on the defensive posturing of turtles from Belize, Central America. Herpetological Review 9:11-12.

Duméril, A.M.C. AND Bibron, G. 1851. [Emys areolata]. In: Duméril, A.M.C. and Duméril, A.H.A. Catalogue Methodique de la Collection des Reptiles (Museum d'Histoire Naturelle de Paris). Paris: Gide and Baudry, 224 pp.

EMMONS, L.H. 1989. Jaguar predation on chelonians. Journal of
Herpetology 23:311-314.

ERNST, C.H. 1978. Arevision of the Neotropical turtle genus Callopsis (Testudines: Emydidae: Batagurinae). Herpetologica 34:113-134.

ERnst, C.H. 1980. Rhinoclemmys areolata. Catalogue of American Amphibians and Reptiles 251.1-251.2.

ERnst, E.M. AND ERnst, C.H. 1975. New hosts and localities for turtle helminths. Proceedings Helminthological Society of Washington 42:176-178.

Ewert, M.A. 1979. The embryo and its egg: Development and natural history. In: Harless, M., and Morlock, H. (Eds.). Turtles: Perspectives and Research. Robert E. Krieger Publishing Company, Malabar, Florida, pp. 333-413.

EwERT, M.A. 1985. Embryology of turtles. In: Gans, C., Billet, F., and Maderson, P.F.A. (Eds.). Biology of the Reptilia. Vol. 14. New York: John Wiley and Sons, pp. 75-268.

Ewert, M.A., AND Nelson, C.C. 1991. Sex determination in turtles: Diverse patterns and some possible adaptive values. Copeia 1991:50-68.

EwerT, M.A., FirT, S.J., AND Nelson, C.E. 1984. Normal and multiple eggshells in batagurine turtles and their implications for dinsosaurs and other reptiles. Canadian Journal of Zoology 62:1834-1841.

Fritz, U. ANd Havas, P. 2007. Checklist of Chelonians of the World. Vertebrate Zoology 57(2):149-368.

FuRLEY, P.A. 1989. Further observations the nature of the savanna vegetation and soils in Belize. In: Munro, D.M. (Ed.). Ecology and Environment in Belize: An account of the University of Edinburgh Expedition to Belize, Central America, 1986. Department of Geography, University of Edinburgh, Occasional Publication No. 12, pp. 9-35.

Highfield, A.C. 1996. Practical Encyclopedia of Keeping and Breeding Tortoises and Freshwater Turtles. Kreiger Publishing Company, Melbourne, Florida, 295 pp.

IUCN. 2007. 2007 IUCN Red List of Threatened Species. http:// www.iucnredlist.org.

IVERSON,J.B. 1992.ARevised Checklist with Distribution Maps of the Turtles of the World. Richmond, IN: Privately printed, $363 \mathrm{pp}$.

LeE, J.C. 1996. The Amphibians and Reptiles of the Yucatan Peninsula. Cornell University Press, Ithaca, NY, 500 pp.

MeERman, J.C. 1993. Checklist of reptiles and amphibians of the Shipstern Nature Reserve. Occasional Papers of the Belize Natural History Society 2:65-69.

PearSe, A.S. 1936. Parasites from Yucatan. Carnegie Institute of Washington, Publ. 457:45-59.

Perez-Higareda, G., and Smith, H.M. 1987. Comments on geographic variation in Rhinoclemmys areolata (Testudines). Bulletin of the Maryland Herpetological Society 23:113-118.

Perez-Higareda, G., AND Smith, H.M. 1988. Courtship behavior in Rhinoclemmys areolata from western Tabasco, Mexico (Testudines: Emydidae). Great Basin Naturalist 48:263-266.

Platt, S.G. 1993. Rhinoclemmys areolata (furrowed wood turtle). Diet. Herpetological Review 24:32.

Platt, S.G., Karesh, W.B., Thorbjarnarson, J.B., and Rainwater, T.R.1999a.Occurrence of the furrowed wood turtle (Rhinoclemmys areolata) on Turneffe Atoll, Belize. Chelonian Conservation and Biology 3:490-491.

Platt, S.G., Meerman, J.C., and Rainwater, T.R. 1999b.Diversity, observations, and conservation of the herpetofauna of Turneffe, Lighthouse, and Glovers Atolls, Belize. British Herpetological Society Bulletin 66:1-13.

Platt, S.G., Finger, A.G., Rainwater, T.R., and Woodke, H. 2004a. Rhinoclemmys areolata (Furrowed wood turtle). Maximum size. Herpetological Review 35:383.

Platt, S.G., Rainwater, T.R., and Brewer, S.W. 2004b. Aspects of the burrowing ecology of nine-banded armadillos in northern Belize. Mammalian Biology 69:217-224.

SoKol, O. 1971. Lithography and geophagy in reptiles. Journal of Herpetology 5:67-71.

Sмith, H.M. AND Smith, R.B. 1979. Synopsis of the herpetofauna of 
Mexico. Vol.6. Guide to Mexican turtles. Bibliographic addendum III. John Johnson, North Bennington, Vermont, 281 pp .

STUART, L.C. 1935. A contribution to a knowledge of the herpetofauna of a portion of the savanna region of central Peten, Guatemala. Miscellaneous Publications of the Museum of Zoology, University of Michigan 29:1-56.

van Dijk, P.P., Lee, J., Calderón Mandujano, R., Flores-Villela, O., AND LOPEZ-LuNA, M.A. 2007. Rhinoclemmys areolata. In: IUCN 2007. 2007 IUCN Red List of Threatened Species. www. iucnredlist.org.

Wright, A.C.S., Romney, D.H., Arbuckle, R.H., AND Vial, V.E. 1959. Land in British Honduras. Colonial Research Publication No. 24. Colonial Office, London, 327 pp.

\section{Citation Format for this Account:}

Vogt, R.C., Platt, S.G., and Rainwater, T.R. 2009. Rhinoclemmys areolata (Duméril and Bibron 1851) - furrowed wood turtle, black-bellied turtle, mojena. In: Rhodin, A.G.J., Pritchard, P.C.H., van Dijk, P.P., Saumure, R.A., Buhlmann, K.A., Iverson, J.B., and Mittermeier, R.A. (Eds.). Conservation Biology of Freshwater Turtles and Tortoises: A Compilation Project of the IUCN/SSC Tortoise and Freshwater Turtle Specialist Group. Chelonian Research Monographs No. 5, pp. 022.1022.7, doi:10.3854/crm.5.022.areolata.v1.2009, http://www. iucn-tftsg.org/cbftt/. 